\title{
ANALYSIS SPOOF TEXT PRODUCTION ABILITY OF CLASS XI HIGH SCHOOL STUDENTS WITH PROBLEM-BASED LEARNING (PBL) APPROACH
}

\section{Evi Safitri Yulandari \& Hendra Suryadi}

\author{
English Lecturer, Faculty of English Language Education, Institut Pendidikan \\ Nusantara Global, Aik Mual, Indonesia \\ Co. Author Email: evisafitri785@gmail.com
}

\begin{tabular}{ll}
\hline \hline Article Info & Abstract \\
\hline Article History & There are 13 types of texts in English, but English teachers rarely teach spoof \\
Received: October 2021 & texts because most teachers are more focused on descriptive text, procedure text, \\
Revised: December 2021 & etc. So, students' understanding of spoof texts was very low, even most students \\
Published: January 2022 & don't know what the spoof text is, and they are not accustomed to producing texts. \\
\hline Keywords & The Problem Based Learning approach was chosen to make it easier for teachers \\
Text production; & to help students produce texts. Therefore, this present study aims to analyze \\
Spoof text; & students' abilities in producing spoof texts by using a problem-based learning \\
Problem-based learning; $;$ & approach. This research used qualitative descriptive and selected class XI \\
& students as a sample of this research. Data collection in this study used the \\
& following instruments: observation, interviews, and questionnaires to analyze the \\
& data in descriptive qualitative form. Based on the results, this study can conclude \\
& that the level of students'ability to produce spoof texts after applying the Problem \\
& Based Learning Approach at the post-test is a complete category. It was proved \\
that an average score of 73.9 and the highest score of 86. The percentage test of \\
students' completeness was $78 \%$, i.e., 14 of 22 students are included in the \\
complete category. In comparison, 22\% are not included in the complete \\
category, meaning that students still need improvement.
\end{tabular}

How to cite: Yulandari, E. S., \& Suryadi, H. (2022). Analysis spoof text production ability of class XI high school students with problem-based learning (PBL) approach, JOLLT Journal of Languages and Language Teaching, 10(1), pp. 36-45 DOI: https://doi.org/10.33394/jollt.v\%vi\%i.4277

\section{INTRODUCTION}

Learning English cannot be separated from four skills, and teachers are demanded to teach those skills integratively. There are four types of skills that students must possess, namely: speaking, listening, reading, and writing (Imran et al., 2019; Nerim, 2020). Because of this, the current study focuses on writing skills centered on the ability to produce texts. Producing texts requires students to be able to make a frame of mind, observe and express ideas or thought that could be poured into the text. Students must be skilled in utilizing the power of expression both from the structure of language, words, and sentences. These writing (producing) skills have to go through a lot of exercise and practice, Wirhayati (2019). Writing or producing text is a valuable skill. It can be said that writing is the main foundation for work and learning both in school or college, in the workplace, and in society. Based on the theory above, the researcher analyzed how the class XI IPA 2 high school students produced spoof texts. Spoof text has a social function for readers with a funny story to entertain, which ends with a twist. However, sometimes students have difficulty in producing spoof texts because they have to express the events in written form. Then they also have difficulty putting together sentences to find twists or unexpected endings.

Spoof text tells a potentially factual story that has happened in the past with an unexpected and funny ending. Its social function is to entertain and share stories. Spoof aims to tell an event with a humorous twist, Nurma (2016). Moreover, the story usually has a moral message for the reader. Sudarwati \& Grace (2016) stated that spoof has a generic structure or 
text organization and language characteristics. Regarding the organization of the text, Djuharie (2017) explains as follows: a) Orientation: orientation appears as an introductory part of the text. This guides the reader to indicate what kind of text he/she reads, and it's also the beginning of the story. b) Events: Events are included as part of the text narrating the events in the story, usually in chronological order. c) Twist: a twist is a part of the text near the end of the story that tells about something unpredictable that makes the reader smile and laugh. This is the funniest part of the story.

According to Djuharie (2017), spoof text has the following language characteristics: 1) Noun: relates to certain people, animals or things in the text. 2) Action verb: deals with verbs that indicate events (eg eat, run, stay, etc.). 3) Connectives: links with a sequence of events (example: first, then, after, before, finally, etc.). 4) Adverb: describes when and where the event occurred (example: at the park, two days ago, etc.). 5) Simple past tense: simple past tense relates to activities that occurred in the past and uses verbs in the past tense. To help students produce spoof text, this study applied problem-based learning as a strategy. Understanding problem-based learning needs to know the word 'problem' as the main focus in learning activities. It is in line with Sumono (2018), who depicts teachers can stimulate learners' curiosity in the learning process. Students can be interested in observing and engaging in something (Hung et al., 2003; Barrows, 1986). This means that students actively participate in the learning process to find solutions.

According to Dasna (2019), problem-based learning or (PBL) is learning based on a case and then analyzed to find solutions to the problems. Problem-based learning encourages students to apply critical thinking and problem-solving skills with content knowledge to real problems or issues. Instruction in learning strategy problems is student-based and studentcentered. Problem-based learning includes discussion, reflection, research, projects, and presentations. Problem-based learning begins with an issue or subject matter, case, or unstructured problem that can be researched, studied, or even solved. The role of a teacher in problem-based learning is to pose problems, ask questions, and facilitate the learning process.

Producing spoof texts requires knowledge and expressive power based on daily experiences or students' reading results. An appropriate and directed approach is needed to achieve effective results in increasing the ability to produce texts, especially spoof texts. The approach is the Problem-based learning (PBL) approach. This approach uses the inner intelligence of learners in their environment to solve meaningful, relevant, and contextual problems (Schmidt, 2014). There are two previous studies that the researcher used for this research. The first study was conducted by Rangkuti (2020), whose research showed the effect of PBL in producing narrative texts with the Zoom application. The results of this study indicate that students' abilities have increased. The second study by Julianti (2018) examined vocabulary errors in producing spoof texts. His research shows that many students have not been able to use expressive ability correctly.

Writing or producing text is one way for students to express their thoughts in written form. Producing text also requires precision, requiring a lot of time to revise the results of the writing. Take into account the choice of words, forms, and grammatical structures, so that readers can easily understand the content of the text. Furthermore, writing is the fourth skill in learning English. In line with Harmer, which states that writing is rewriting, viewing, or revising has a central role in creating text. Harmer (2018) points out that 'there are a number of reasons why students find it difficult to produce language.' Writing and learning to write is one of the most complex language skills. Nunan (2018) agrees that 'it is easier to learn to speak than to write, whether it is a first or a second language. This complexity lies in the stages of the process that students go through when writing or producing texts and the lack of knowledge about the subject matter. Writing is often taught in such a way that students fail to focus on the writing process. The process of writing is familiar to students at school and its environment. Creative 
language, intense thinking, and critical reasoning make for great artificial writing. There are three general purposes of writing, and all of them can occur in one writing or essay, although usually one of the goals is more dominant, namely: to explain (educate, inform), entertain (give pleasure), and to persuade (convince, change the reader's mind).

Problem Based Learning (PBL) encourages students to gain a deeper understanding, using problem-based learning that students combat by always introducing vocabulary to real classroom situations, so they don't have to memorize vocabulary they don't need, Larsson (2018). This can make it easier for students to write or produce texts. With problem-based learning, students receive passive knowledge and are required to actively acquire that knowledge. This research will only photograph students' ability to produce spoof texts, but together with three research topics that other research members will carry out, namely: (a) whether or not teachers are able to teach spoof text writing skills using the PBL approach, (b) how teachers run the PBL approach, and (c) students' understanding in producing spoof texts and PBL-based learning.

Based on the two previous studies, there is no current study on producing spoof text using the PBL approach, especially during the current pandemic. The selection of this research is expected to provide an increase in students' ability to produce spoof texts with a PBL approach at the secondary education (Senior High School) level. This study focused on problems related to the analysis of improving the skills of producing spoof texts using the Problem Based Learning (PBL) approach. Using this type of qualitative descriptive research and selected as a sample class XI students. Data collection in this study used the following instruments: observation, interviews, and questionnaires to analyze the data in descriptive qualitative form. More specifically, this research is expected to be able to describe (1) whether the teacher is able to implement or not teach spoof text writing skills using the PBL approach; (2) how teachers implement the PBL approach; (3) Students' understanding in producing spoof texts and PBL approach-based learning.

\section{RESEARCH METHOD Research Design}

This research used descriptive qualitative. According to Sugiyono (2010), qualitative research is research in which the researcher is placed as the key instrument, the data collection technique is carried out in combination, and the data analysis is inductive. According to Poerwandari (2017), qualitative research produces and processes descriptive data, such as transcripts of interviews and observations. Kirk and Miller ${ }^{16}$ reveal that qualitative research is a way to make direct observations of individuals and relate to these people to get the data that researchers want, Moleong (2017). This research has been carried out for three months. The research was carried out by the head of the research team, research members and assisted by English teachers who teach at the research location to obtain research data. The subjects of this study were students of class XI IPA 2 Senior High School of MA Darul Aminin Aik Mual Lombok Tengah, Mataram, in the academic year 2021/2022. There is only one class that became the research sample.

\section{Research Instruments}

To collect the data needed in this study, the instruments used consisted of observations, interviews, and questionnaires. Writing spoof texts was done after the teacher had finished teaching two or three times with the PBL approach so that students were more adapted to the material being studied. The teacher asks students what they think and feel when they learn to write spoof texts using PBL in the teaching and learning process, and students will answer questions in the form of interviews and questionnaires. In the interview guide, several questions are written to guide the interview. Because this study uses semi-structured interviews, the 
questions that have been prepared in the interview guide can be developed during the interviews. The interview guide was used to collect more information from students about during the learning they were doing, whether they liked to learn to write spoof texts through the PBL approach or not in the teaching and learning process. The subjects of this study were students of class XI IPA 2 Senior High School of MA Darul Aminin. At the same time, the object of this research was the skill of writing spoof text using the Problem Based Learning (PBL) approach.

\section{Data Analysis}

In analyzing the descriptive qualitative data, the researcher has conducted the mean scores of writing achievement scores by Sugiono (2013, p.49). The data are in the form of students' scores from the action at the beginning and final of research and the test given after the teaching and learning spoof text using the problem-based learning (PBL) approach. In analyzing the descriptive qualitative data, the researcher did some steps proposed by Burns (2010, pp. 104-105). The first step was assembling the data. In this step, look for broad patterns, ideas, or trends that seem to answer the questions. The next step was coding the data. In this step, the researcher groups the data into more specific categories and identifies which data are. The third step was comparing the data. In this step, the researcher compares the categories of different sets of data to see whether the data said the same thing or whether there are contradictions. The fourth step was building meanings and interpretations. The researcher analyzes the data several times to post questions, rethink connections, and explain the situation. The fifth or the last step was reporting outcomes. In this step, the researcher describes the research context, outlines findings, and considers how she organized the whole research, the analysis, and the findings.

\section{RESEARCH FINDINGS AND DISCUSSION Research Findings}

The implementation of the Problem Based Learning approach in learning to produce spoof texts was carried out at MA Darul Aminin class XI IPA 2 high school students for approximately three months, from April to June. At this stage, the learning process was carried out in accordance with the learning implementation plan (RPP) that has been made. At the beginning of the study, the researcher found that MA Darul Aminin students, especially Class XI IPA 2, had difficulties in learning English, especially in writing or producing texts. Students have low motivation to learn English and are afraid to make mistakes. They have a relatively low mastery of vocabulary, so that it becomes an obstacle when they want to write their ideas well. In addition, there is also the fact that English teachers only use books or worksheets as the media in their teaching and learning process.

After completing the observation as well as the pre-test, the researcher found several problems faced by the students of science class XI IPA 2. To assess the writing of the students, the researcher referred to the writing assessment system given the scale by Jacobs (2002); writing or producing texts can be assessed on five aspects of writing: content, organization, vocabulary, language use, and mechanics. The five aspects were given different weights to emphasize the first content (30 points) and subsequent language use (25 points), with organization and vocabulary being equally weighted (20 points) and mechanics receiving less emphasis (5 points). For more details can be seen in the following table.

Tabel 1

Scheme of Scoring Writing

\begin{tabular}{lll}
\hline Content & & \\
\hline $30-27$ & Excellent to very good & Knowledgeable-substantive-etc \\
\hline $26-22$ & Good to average & Some knowledge of subject-adequate range-etc
\end{tabular}




\begin{tabular}{|c|c|c|}
\hline $21-17$ & Fair to poor & Limited knowledge of subject-little substance-etc \\
\hline $16-13$ & Very poor & $\begin{array}{l}\text { Does not show knowledge of subject non-substantive- } \\
\text { etc }\end{array}$ \\
\hline \multicolumn{3}{|c|}{ Organization } \\
\hline $20-18$ & Excellent to very good & Fluent expression-ideas clearly stated-etc \\
\hline $17-14$ & Good to average & $\begin{array}{l}\text { Somewhat choppy-loosely organized but the main idea } \\
\text { stand out-etc }\end{array}$ \\
\hline $13-10$ & Fair to poor & Non fluent-ideas confused or disconnected-etc \\
\hline $9-7$ & Very poor & Does not communicate-no organization-etc \\
\hline \multicolumn{3}{|c|}{ Vocabulary } \\
\hline $20-18$ & Excellent to very good & $\begin{array}{l}\text { Sophisticated range-effective word/idiom choice and } \\
\text { usage-etc }\end{array}$ \\
\hline $17-14$ & Good to average & $\begin{array}{l}\text { Adequate range-occasional errors of word/idiom, } \\
\text { choice, usage but the meaning not obscured }\end{array}$ \\
\hline $13-10$ & Fair to poor & $\begin{array}{l}\text { Limited range-frequent errors of word/idiom form, } \\
\text { choice, usage-etc }\end{array}$ \\
\hline $9-7$ & Very poor & $\begin{array}{l}\text { Essentially translation-little knowledge of English } \\
\text { vocabulary }\end{array}$ \\
\hline \multicolumn{3}{|c|}{ Language Use } \\
\hline $25-22$ & Excellent to very good & Effective complex constructions-etc \\
\hline $21-19$ & Good to average & Effective but simple constructions-etc \\
\hline $17-11$ & Fair to poor & Major problems in simples/ complex constructions-etc \\
\hline $10-5$ & Very poor & Virtually no mastery of sentence constructions rules- etc \\
\hline \multicolumn{3}{|c|}{ Mechanics } \\
\hline 5 & Excellent to very good & Demonstrated mastery of conventions-etc \\
\hline 4 & Good to average & Occasionally errors of spelling, punctuations-etc \\
\hline 3 & Fair to poor & $\begin{array}{l}\text { frequent errors of spelling, punctuations, capitalization- } \\
\text { etc }\end{array}$ \\
\hline 2 & Very poor & $\begin{array}{l}\text { No mastery of conventions-dominated by errors of } \\
\text { spelling, punctuations, capitalization, paragraphing- etc }\end{array}$ \\
\hline
\end{tabular}

After analyzing the students' pre-test data using the assessment format by Jacobs (2002); Researchers can find some problems faced by students. The results of the average value of the pre-test that has been carried out by the students will be shown in the following table.

Table 2

The average score of XI IPA 2 high school students after carrying out the pre-test

\begin{tabular}{lllllll}
\hline \multirow{2}{*}{ MEAN } & $\mathrm{C}$ & $\mathrm{O}$ & $\mathrm{V}$ & $\mathrm{L}$ & $\mathrm{M}$ & Total \\
\cline { 2 - 7 } & 15.18 & 15.9 & 15.27 & 14.95 & 3 & 65.7 \\
\hline
\end{tabular}

C: Content O: Organization

V: Vocabulary L: Language use M: Mechanics

The average score of students in the Content aspect of writing or producing texts reached 18.3 out of 30, including in the good and medium categories. They have some knowledge of the subject and adequate range, but the writing development is still limited. The content of the article was most relevant to the topic but still lacks supporting details. Students generally have difficulty in generating and expressing their ideas in English because it takes a long time. In the organizational aspect, students, on average, managed to reach 17 out of 30 . This scoring range was included in the medium category. They already have the main ideas that stand out. However, it still has limited storylines and incomplete story sequences. In terms of vocabulary, students' writing results generally show that they have an adequate range of vocabulary because they get a score of 15 out of 20 . Although some of them still make mistakes in their word choice. The students achieve 15 out of 20 in Language use. It was categorized as good to average. And 
Mechanics reached 3 out of 5. That's categorized pretty badly. Student writing products have a simple construction but are quite effective. They show some errors in choosing verbs, word order/function, articles, and pronouns.

To better understand the problems faced by students, the researcher will explain the problem in detail using the following table.

Table 3

Problems faced by students

\begin{tabular}{|c|c|c|}
\hline NO. & Problems & Observation results \\
\hline 1. & Students Attitude & $\begin{array}{l}\text { - There are many students who prefer to play and chat with their friends rather } \\
\text { than doing their assignments. } \\
\text { - Most of them claim that English is one of the most difficult subjects. } \\
\text { - They consider English lessons especially writing or producing texts to be } \\
\text { monotonous and uninteresting. }\end{array}$ \\
\hline 2. & $\begin{array}{l}\text { Students ability to } \\
\text { produce texts } \\
\quad \text { a. Content }\end{array}$ & $\begin{array}{l}\text { - Most of the students do not have sufficient knowledge about the stories they } \\
\text { produce. } \\
\text { - They do not provide sufficient supporting details. } \\
\text { - They find it very difficult to come up with ideas for producing texts. } \\
\text { - They took a very long time to produce a story that they already knew } \\
\text { because they had no idea to produce or write it. } \\
\text { - Students lack confidence to produce funny stories }\end{array}$ \\
\hline & b. organization & $\begin{array}{l}\text { - They don't produce funny stories in perfect order. Sometimes they jump in } \\
\text { and make the story confusing. }\end{array}$ \\
\hline & c. vocabulary & $\begin{array}{l}\text { - Students make many mistakes while writing and use irregular verbs as } \\
\text { regular verbs. } \\
\text { - The students don't realize adjectives and verbs like "life" when they should } \\
\text { write "live". }\end{array}$ \\
\hline & $\begin{array}{l}\text { d. Grammar and } \\
\text { Mechanics }\end{array}$ & $\begin{array}{l}\text { - Most of them do not use the past tense in producing the funny stories that } \\
\text { they already experienced } \\
\text { - They produce sentences with wrong grammar. } \\
\text { - Some students do not use capital letters for the first letter at the beginning } \\
\text { of a sentence and for certain words or objects. } \\
\text { - Students do not put a full stop to indicate the end of the } \\
\text { sentence/paragraph. }\end{array}$ \\
\hline
\end{tabular}

After knowing the problems experienced by students of XI IPA 2 MA Darul Aminin, the researchers prepared spoof text material to be applied to students at the next meeting, by referring to the Problem Based Learning approach, a problem-oriented learning approach and students are required to develop thinking skills, solve problems, and find solutions to the problems faced both individually and cooperatively, Rusman (2019). By referring to this, the research results are expected to obtain maximum results.

\section{Discussion}

There are five reasons for this research happened. The first reason is that although PBL has been around for nearly 50 years now, there are still questions about its effectiveness. One of the proposed strategies is PBL. It has been to understand why and how the underlying principles of PBL (learning is contextual, constructive, collaborative, self-directed and engaging) work, and under what circumstances (Dolmans, De Grave, Wolfhagen, \& Van der Vleuten, 2005; Mamede, Schmidt, \& Norman, 2006). To understand how and why PBL works, it is essential to know more about the foundational elements of PBL such as problems, tutors, and students. The second reason is that several studies suggest the quality of problems to be important in positively influencing the students' learning (Gijselaers \& Schmidt, 1990; Van Berkel \& Schmidt; 2000). It is shown to have a higher influence on students' learning than 
teacher role and students' prior knowledge (Gijselaers \& Schmidt, 1990; Van Berkel \& Schmidt; 2000).

The implication of these findings is that understanding how to improve the quality of the problem is likely to be meaningful and crucial to enhancing the students' learning. The third reason is that despite the suggested importance of quality of problems in PBL, only a few studies are available that shed light on this matter. What this means is that though the researcher recognizes the importance of problems, the researchers do not know much about the characteristics of problems that determine the quality of problems. The fourth reason is that problem students find the process of answering the questions problems challenging and the lack of framework based on empirical evidence to guide them indicates that there is not much support for students' problems. Hence, there is a need to gain a better understanding of problems in PBL to help the students' problems, so that the researcher and the teacher can help students learn better.

The fifth reason is a lack of validated instruments available to assess the quality of individual problems in PBL. Hence, assessing the quality of the problem may not be straightforward. Therefore, there is a need to develop and validate an instrument to assess the quality of problems so that the researcher and teacher can evaluate and design better problems. Underpinning all the above five reasons was the vision to help students learn better in PBL. Therefore, the objective of this research is to explore the students' and teacher perspective of problem characteristics, develop and validate a rating scale to assess the quality of problems, and utilize this rating scale to investigate the influence of problem characteristics on students' learning. More specifically, it investigates (1) whether the teacher is able to implement or not teach spoof text writing skills using the PBL approach; (2) how teachers implement the PBL approach; (3) Students' understanding in producing spoof texts and PBL approach-based learning.

The text used in this research was a spoof text. Spoof is a text that tells a potentially factual story that has happened in the past with an unexpected and funny ending. Its social function is to entertain and share stories. Spoof aims to tell an event with a humorous twist, Nurma (2016). Moreover, the story usually has a moral message for the reader. Sudarwati \& Grace (2016), stated that spoof has a generic structure or text organization and language characteristics. Regarding the organization of the text, Djuharie, O. S. (2017) explains as follows: a) Orientation: orientation appears as an introductory part of the text. This will guide the reader to indicate what kind of text he will read and the story's beginning. b) Events: Events are included as part of the text narrating the events that occur in the story usually in chronological order. c) Twist: a twist is a part of the text near the end of the story that tells about something unpredictable that makes the reader smile and laugh. This is the funniest part of the story.

Assessment of student was carried out by giving post-tests. The post-test results support the successful use of the problem-based learning method in improving students' text-producing skills. Assessments for writing or text production were conducted to measure the improvement of students' text-producing skills and to support data. Researchers made several indicators of writing performance, including content, vocabulary, organization, language use and mechanics, and presented students' average score in each aspect of writing after the post-test process. For more details can be seen in the following table.

For the post-test, the average student's writing results got a score of 73.9. This Shows students' abilities are at a better level than before. In the pre-test, they only got a score of 65.7. The average score of students from each aspect of producing texts showed a significant increase compared to the previous measure. In terms of content, students managed to get 19.18 out of 30. This was in the good to average category. They have adequate knowledge and supporting sentences, although some still lack detail. However, content development is sufficient. 
The students also have more organization, with a score of 17.81 . The main idea was fairly well written and fairly cohesive. Students' ideas in producing texts are also more prominent and logical. They can also provide a logical and well-organized sequence when compared to their writing at the time of the pre-test. In the use of language use, students got a score of 16.45 out of 20 . Their writing has effective and simple constructions and shows minor problems in complex constructions. Students wrote more in the correct tenses although sometimes they made some mistakes, but it was less than before. There are still some students who forget to put a period at the end of the sentence and use capital letters in certain conditions. In terms of spelling, they show fewer punctuation errors.

The increase in student learning outcomes occurs because the application of Problem Based Learning approach was applied systematically so that students can develop learning motivation, collect data, and information from various sources. This is in line with Rusman (2019) opinion, which states that the purpose of PBL is mastery of learning content from heuristic disciplines and the development of problem-solving skills. The problem-based learning approach uses the inner intelligence of humans in the community or environment to solve meaningful, relevant, and contextual problems. Problem-based learning is the most significant innovation in education. PBL is also related to learning about the wider life (lifewide learning), skills to interpret information, collaborative and team learning, reflective and evaluative thinking skills.

According to Dasna (2019), problem-based learning or (PBL) is learning that is based on a case and then analyzed to find solutions to problems. Problem-based learning encourages students to apply critical thinking and problem-solving skills with content knowledge to real problems or issues. Instruction in learning strategy problems is student-based and studentcentered. Problem-based learning includes discussion, reflection, research, projects, and presentations. Problem-based learning begins with an issue or subject matter, case, or unstructured problem that can be researched, studied, or even solved (give a solution). The role of a teacher in problem-based learning is to pose problems, ask questions, and facilitate the learning process.

\section{CONCLUSION}

Based on the results of the study, it shows that students' writing skills can improve through the application of the Problem Based Learning model. Students can improve their ability to produce spoof texts that include aspects of content, text structure (organization), vocabulary, sentences used (language use), and mechanics after the action research has been carried out from the pre-test to the post-test. The implementation of the Problem Based Learning model shows a significant increase in students' ability to produce spoof texts. This learning approach was problem-oriented to develop thinking skills, solve problems, and find solutions to issues faced both individually and cooperatively. Therefore, problem-based learning is an innovation in learning. In PBL, students' thinking skills are really optimized through a systematic group or teamwork process. Students can empower, hone, test, and develop their thinking skills effectively. In addition, the role of teachers has very important in the delivery and selection of learning methods that are in accordance with the material to be taught. The influence of the ability of a teacher who has the experience and good language skills will have an impact on student learning outcomes so that in the process of delivering learning, students are more responsive to the material being taught.

This study can conclude that the level of students' ability to produce spoof texts is average after applying the Problem Based Learning model. It was proved by the post-test obtained an average score of 73.9 ideal scores of 100, the highest score of 86 and the lowest score of 66. The percentage test of students' completeness was $78 \%$, ie 14 of 22 students are included in the complete category while $22 \%$, namely 6 out of 22 students, are not included in 
the complete category, meaning that there are still students who still need improvement. However, at this time, it is considered complete because it has met the criteria for indicators of the success of student learning outcomes.

\section{REFERENCES}

Barrows, H. S. (1986). A taxonomy of problem-based learning methods. Medical Education, 20(6), 481-486. https://doi.org/10.1111/j.1365-2923.1986.tb01386.x

Burns. Anne. (2010). Doing Action Research in English Language Teaching. New York: Routledge.

Dasna, W. I \& Sutrisno. (2019). Pengaruh pembelajaran berbasis masalah (Problem Based Learning) terhadap kemampuan berpikir kritis siswa pada mata pelajaran PKn Kelas VI di SDN Kota Sumenep. ELSE (Elementary School Education Journal): Jurnal Pendidikan dan Pembelajaran Sekolah Dasar, 3(2), 98-110. http://103.114.35.30/index.php/pgsd/article/view/3394

Djuharie, O. S. (2017). An error analysis on students'spoof text writing (a Case study at eleventh grade of Sman 5 kota serang) (Doctoral dissertation, Universitas Islam Negeri" Sultan Maulana Hasanuddin" BANTEN). http://repository.uinbanten.ac.id

Handayani, N. D., \& Harha, K. (2016). Problems in Writing Spoof Texts. Studies in English Language and Education, 3(1), 12-25. http://www.e-repository.unsyiah.ac.id

Harmer, J. (2018). The Application of Language Awareness in College English Writing Teaching. Open Journal of Modern Linguistics, 8(03), 54. https://www.scirp.org/html/31640666 85537.htm

Hung, W., Harpole Bailey, J., \& Jonassen, D. H. (2003). Exploring the Tensions of ProblemBased Learning: Insights From Research. New Directions for Teaching and Learning, 2003(95), 13-23. https://doi.org/10.1002/tl.108

Imran, F., Firman, E., \& Raudhatunnisa, S. (2019). Applying think-talk-write (TTW) in the teaching of reading comprehension in relation to students' critical thinking skills. JOLLT Journal of Languages and Language Teaching, 7(1), 57. https://doi.org/10.33394/jollt.v7i1.1439

Julianti, W. (2018) Analyzing the students' grammatical error in spoof text writing of the twelfth grade at the first semester of Sman 1 Belalau Lampung Barat in Academic Year Of 2017/2018. UIN Raden Intan Lampung. http://repositori.radenintan.ac.id/id/eprint/3270.

Jacobs, V. A. (2002). Reading, writing, and understanding. Educational leadership, 60(3).

Larson, J. S., (2018). Using problem-based learning to enable application of foundation engineering knowledge in a real-world problem. In 2018 IEEE International Conference on Teaching, Assessment, and Learning for Engineering (TALE) (pp. 500-506). https://ieeexplore.ieee.org/abstract/document/8615329

Moleong, L. J. (2017). Perilaku inovatif pada mahasiswa yang berwirausaha (Doctoral dissertation, UIN Sunan Ampel Surabaya). http://digilib.uinsby.ac.id/18827/

Nerim, N. (2020). Scrutinizing Directed Reading thinking activity (DRTA ) Strategy on Students' Reading Comprehension. JOLLT Languages and Language Teaching, 8(2), 128-138. https://doi.org/10.33394/jollt.v8i2.2284

Nunan, D. (2018). "The effectiveness of student teams achievement division to teach writing viewed from students'creativity". Exposure: Jurnal Pendidikan Bahasa Inggris, 7(2), 106-116. https://journal.unismuh.ac.id/index.php/exposure/article/view/1699

Nurma, K. (2016). Problem in writing spoof, Nurma,Khairul,Volume 3 No 1,March 2016, p.117 http://repository.radenintan.ac.id 
Poerwandari, E.K. (2017). Perilaku inovatif pada mahasiswa yang berwirausaha (Doctoral dissertation, UIN Sunan Ampel Surabaya). http://digilib.uinsby.ac.id/18827/

Rangkuti, N. A. (2020). The effect of based learning on the students creative thinking skill in writing narrative text. http://repositori.umsu.ac.id/xmlui/handle/123456789/14008.

Rusman. (2019). Pengaruh profesionalisme guru terhadap hasil belajar siswa di sdn branta paseser iii tlanakan pamekasan. Mubtadi: Jurnal Pendidikan Ibtidaiyah, 1(1), 62-72. http://ejournal.iainmadura.ac.id/index.php/ibtida/article/view/3000

Schmidt, H. G. (2014). Problem-Based Learning. In W. C. Cockerham, R. Dingwall, \& S. Quah (Eds.), The Wiley Blackwell Encyclopedia of Health, Illness, Behavior, and Society (pp. 1881-1885). John Wiley \& https://doi.org/10.1002/9781118410868.wbehibs528

Sudarwati \& Grace. (2016). Problem in Writing Spoof". Nurma,Khairul,Volume 3 No 1,March 2016,p.17 http://repository.radenintan.ac.id

Sugiyono. (2010). Metode Penelitian Kuantitatif Kualitatif \& RND. Bandung : Alfabeta

Suhendra, Y. \& Sundayana, W. (2016). Efl teachers'understanding in developing lesson plan. Indonesian EFL Journal, 2(1), 1-11. https://journal.uniku.ac.id/index.php/IEFLJ/article/view/632

Sumono. (2018). The implementation problem based learning to improve students writing skill at eighth grade of smp n 2 salam (Doctoral dissertation, IAIN SURAKARTA).

https://scholar.google.com/scholar?hl=id\&as_sdt=0\%2C5\&q=Sumono\%2C+\%282018\%29.+ THE+IMPLEMENTATION+PROBLEM+BASED+LEARNING

Sundayana, W., Alwasilah A.C. et al. (2016). Efl teachers'understanding in developing lesson plan. Indonesian EFL Journal, 2(1), 1-11. https://journal.uniku.ac.id/index.php/IEFLJ/article/view/632

Wirhayati, W. (2019). A picture of the ability to write a journal daily by students of english department. Proceedings Universitas Pamulang, 9(1). http://openjournal.unpam.ac.id/index.php/Proceedings/article/viewFile/2993/2314 